\title{
新土壤水分測定法(Momin 法の実施)
}

\author{
久保次郎 \\ (中央氮像台)
}

A new method for the soil moisture measurement

J. KuBO

(Central Meteorological Observatory.)

\section{1. 緒}

言

土壤水分の測定法には種々の力法(1)が岕るが，現在の

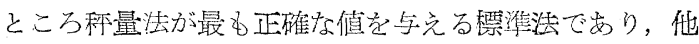
の種々な方法は，实験的の域を脱しないものが多く、ル ーチン観測に採用するには，まだ蜼点が多い。

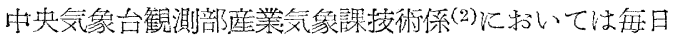
10 時汇土壤水分（地䒾，梁さ $5 \mathrm{~cm}$, 欢び $10 \mathrm{~cm}$ )を観 測しているが，勿論科量法によつている。

科量法は最も正確な土堛水分量を与えるが，ただ供武 土䱋の乾燥には少く々も8 時間を要するので(3), 採土 し，寸ぐその場で土壤水分量を知ることは出来ない。こ のような点を考えると，幾分正確さを欠いても直ちに 土壤水分量を知りらる簡単な測器が考案されれば非常に 便利であり，又全国各地で土壤水分観測を行らことも容 易となる。

幸い, 最近，インドの Poona の農業気像観測所比和 いて採用している簡単で好結果をえている方法の紹介が おつたので，同様の原理を用いた装置を試作し検討して みた。

\section{2. 理論と装置}

（i）新土壤水分測定法は一種の熱伝導を利用する方 法で，A. U. MOMIN の発表した方法である。

從来の熱伝尊利用の方法では，土壤中に埋金属板 を電気的炕熱して測温するのであるが，この方法住取报 いが相当面倒である。气れで，MOMIN は水銀温度計の 球部の後半部を加熱線で巻き(この加熱部分は土壤と電 気的熱的绝緣声る)，これ机一定電流を流して球部を 加熱し, 温尿が $5^{\circ} \mathrm{C}$ 上昗するに要する時間 (秒)を測定 している。

この方法の原理は，球部内では朋熱線を卷かれた半部 分は熱を得，士壤と接触している他の半部分㤬，士壤の

\footnotetext{
* 昭和 27 年 12 月 6 日秋季例会にて発表
}

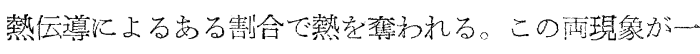
つの球部内で同時化扢こるから，温度計飞おいてある一 定温度上妍させる化要する時間性，土壤の乾湿に上り異 なり，土壤が乾燥しているときより湿つているときのほ らが長いわけである。

以上の Poona 飞斿计る MOMIN の報告では, 温度 $5{ }^{\circ} \mathrm{C}$ 上鼠させると要する時間と科量法に上る土壤水分と の間涪い相関を得ている。

(ii） MOMIN の測定装置の大略は知りらるのである が，一番重要な加熱部の詳細が不明である。そこで笔者 は, Fig. 1 亿示したように水銀棒状温度訫 $\left(1 / 5^{\circ} \mathrm{C}\right)$ を 用いた装置を製作した。

加熱線はエナメル・コンスタンタン線 (S. W. G. 38 番） 2 本撚りとし，全抵抗 $5 \Omega$ で嵓る。加熱部は雲母 板と, オイル・シルクで二重㳊緣を旅し，表面には絶

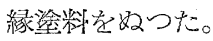

加蓺用電源は蓄電池でもよいが，筆者は Fig. 1 亿示 すように艾流 $100 \mathrm{~V}$ から任意の低電压直流を作り，之

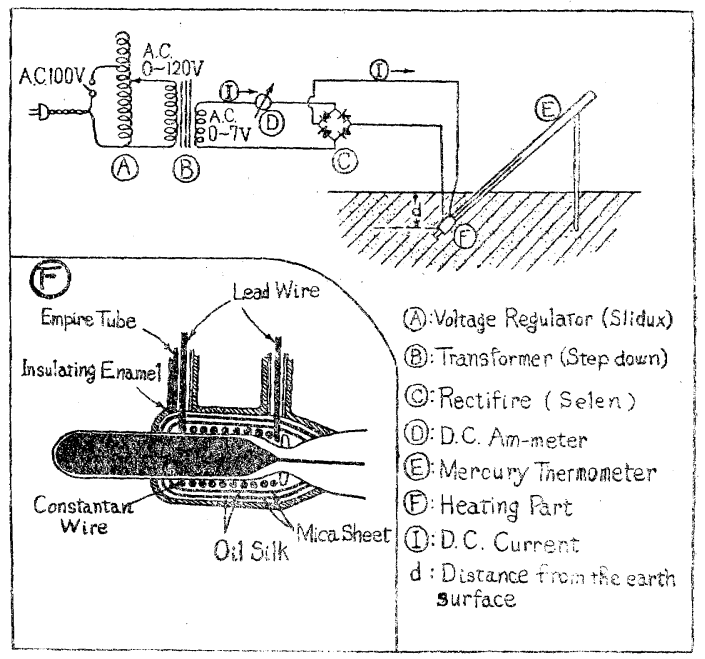

Fig. 1. Now apparatus for the soil moisture measurement and the section of heating part 


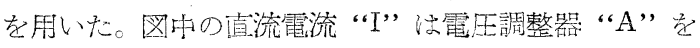

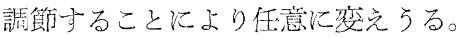

\section{3. 試験 結果}

新方洁による測定装置について決定すべき項目は次の と赤りである。

(A) 加蓺部に要する適当な電流值，これは幾つかの 一定電流について，加熱時間と温度上弹の関係を調 ベることにより沃定できる。

(B) 一定の温度上昇を何度にするか，これは（A） で決定した一定電流のもとで，加蓺時間と温度上昇 との関係を土壤水分別に求めて決定される。

（C），(A)（B）が沃定されれば，一定温度上昇させ るに要する時間と土壤水分の関係を求めることがで きる。

笑際に必要なのは（C）項のみであるが，(A) (B) が波定されなけれげ（C）は求めることができない。

\section{（I）試験用小採土場の土壤についての試験}

面積 $1 \mathrm{~m}^{2}$ の小採土場を特に作り，ぬず新装置を深さ $2 \mathrm{~cm}$ の土壤水分を対称にして試験した。採土場の土壤 は火山灰土質埴壤士である。

(a) 加熱電流別，加熱時間と温度上昇との関係

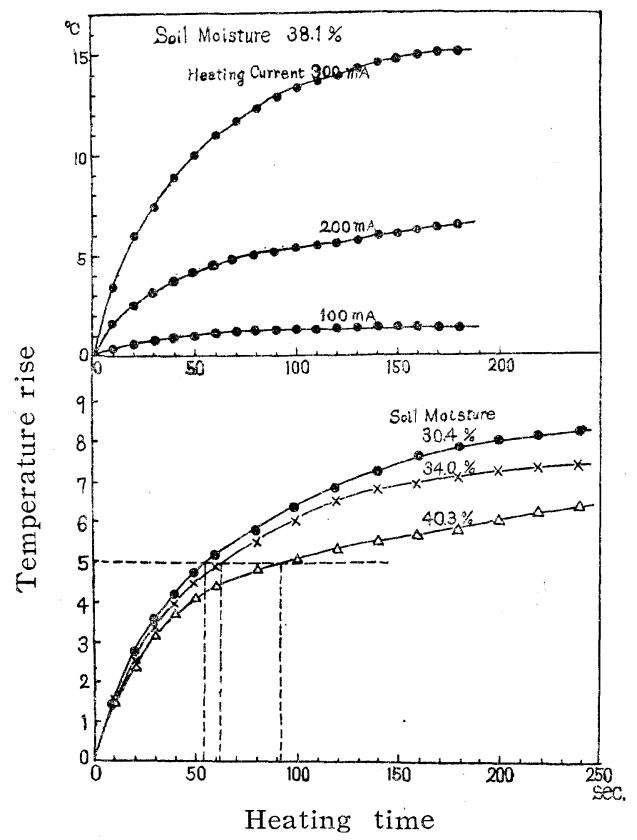

Fig. 2. Relation between the heating and the temperature rise
加蓺部に要する電流值をどの程度にすればよいかが第 一の間題である。装置に電流を通ずると温度計中の水銀 は地中温度の值から上昇しはじめる。加熱電流 100,200 $300 \mathrm{~mA}$ の三種について, 加熱時間と温度上昇との関係 を調ベたものが Fig. 2 の上欄に示したものである。図 から明らかのように，加熱電流 $100 \mathrm{~mA}$ では温度上昇 はきわめて少く，実用にならない。観測誤差をなるべく 少なくするためには，加蓺時間は短かすぎても又長すぎ ても具合が覀い。温度上昇 $5^{\circ} \mathrm{C}$ 内外の值を目縹とする と，箨者の装置では $200 \mathrm{~mA}$ が適当とみられ，この電 流值を用いることにした。

(b) 土壤水分別，加蓺時間と温蔗上昇との関係 加熱電流を $200 \mathrm{~mA}$ としたから，この場合について 地中温度より何度 $\left({ }^{\circ} \mathrm{C}\right)$ 上昇させるかを決定しなければ ならない。文，土壤水分は $50 \%$ くらいまで測定出来な 计れば勿論実用にならない。このためにば各種の土譬水 分の場合について，加熱時間と温度上舁との関係を検討 する必要があり，この一例が Fig. 2 の下闌に示したも のである。MOMIN の報告では $5^{\circ} \mathrm{C}$ 昇温させることに しているが，筆者の装置についても Fig. 2 から判是す るとき, $5^{\circ} \mathrm{C}$ 前後が適当である。ここで筆者の装置につ いては $5^{\circ} \mathrm{C}$ 犁温させるに要する加熱時間を測定するこ とにした。

（c）土壤水分と温度 $5^{\circ} \mathrm{C}$ 上昇させるに要する時閆 との関係

加熱電流, $200 \mathrm{~mA}$, 温度 $5^{\circ} \mathrm{C}$ 上昇させるに要する時 間 ( $\mathrm{t}$ sec.) と, このときの科量法により測つた土褧水 分 $(\omega \%)$ との関係を図に示して和けば，任意の時に直 らに土壤卌分を知ることができるわけである。

我々が普通観測する土瓖水分の範国内では MOMIN も

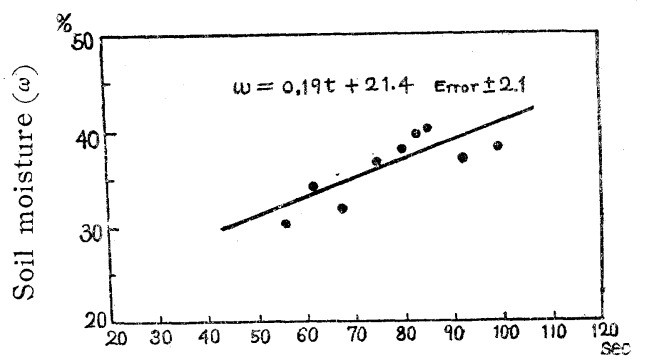

Heating time required for temperature rise of $5^{\circ} \mathrm{C}(\mathrm{t})$

Fig. 3. Relation between the heating time required for temperature rise of $5^{\circ} \mathrm{C}$ and the soil moisture 
示しているように山は情の一次函数で示されるようて ある。

試験に際しては，なるべく东分变化の大きい地表に近 い，滐さ $2 \mathrm{~cm}$ を対象とした。装置の破損，改造等で， 実際えられた測定值は数が少いが，結果はFig. 3 に示 したよ5に尔る。直線の関係式は次のと和りである。 $\omega=0.19 \mathrm{t}+21.4$ 䛊美 \pm 2.1

$\omega$ : 土瓖水分 $\%$ ，測定範囲：30 41\%

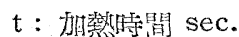

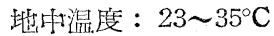

\section{(II) その地の試 験}

Fig. 3 に示した $5^{\circ} \mathrm{C}$ 昇温させるに要する畤間と土壤 水分の関係は，土壤の種類，組織，構造が異つた場合に は，当然異つた関係を示す箱で岁る。

このため，組織の異なる土壤について試験した結羁，

（I）とは異なるが，やはり直線関係が得られることが わかつた。

\section{4. 結言}

新土壤水分测定装置についての試験結果は，装置の破
損，特に lead wire の断線，加等部の作り直し等で， 測定しえた結果はなだ満足ではなかつた。しかし既仙示 したような構造でるつて, Momin の示している結果を 確認すること恃できた。

本装置は，実際には地中温度の変化が大きいときには Fig. 3 K示したよ5な直線関係を少くとも2〜3 種の 温度範囲につき沠定しておかなければならない。

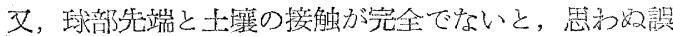

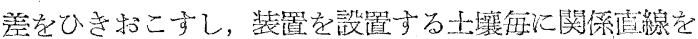

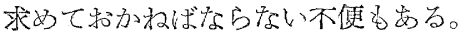

しかし，一定場所についてのルーチン観測には，䩀合 都合がよいと考えられる。

註

（1）日下部正雄：土壤水分の観測法攻び 2.3 の

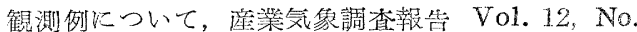
2, p.14 (1948)

（2）この当時は 埼玉県北足立郡大和田町西崛

（3）山中圆利：自然状態市る土壤水分の研究 廉業気像調查報告 Vol. 14，No. 3， p.20 (1950)

(4) 谷 信穓: Poona 気象台農業気象部の新測器 攻び実験技術の研究農業受象 Vol. 6, No. 1 . p. $50(1950)$

\section{Résumé}

The basic principle of the author's new apparatus is almost the same with that of A. U. MoMIN. (c.f. Agricultural Meteorology Vol. 6, No. 1, p. 50)

Namely, the author made a special mercury thermometer in which the half part of the bulb was wound by the electrically heating wire. (c.f. Fig. 1)

When the bulb which was buried in the soil is heated by a constant current, the time which was required for the temperature rise of a certain degree in the temperature is proportional to the soil moisture. So we can easily find the value of soil moisture by measuring the heating time is required for a constant temperature rise.

The author estimated the value of heating current and temperature rise as follows. heating current $=200 \mathrm{~mA}$ temperature rise $=5^{\circ} \mathrm{C}$ (c.f. Fig. 2)

- Under above conditions, the author investigated on the relation between the heating time required for temperature rise of $5^{\circ} \mathrm{C}$ and the soil moisture. (c.f. Fig. 3) 